\title{
Liang-Ge-San, a classic traditional Chinese medicine formula, protects against lipopolysaccharide-induced inflammation through cholinergic anti-inflammatory pathway
}

\author{
Jun-Shan Liu ${ }^{1, *}$, Xi-Duan Wei ${ }^{1, *}$, Zi-Bin Lu, ${ }^{1, *}$, Pei Xie ${ }^{1}$, Hong-Ling Zhou ${ }^{1}$, Yu-Yao \\ Chen ${ }^{1}$, Jia-Mei Ma ${ }^{1}$ and Lin-Zhong $\mathbf{Y u}^{1}$ \\ ${ }^{1}$ Department of Traditional Chinese Medicine, Southern Medical University, Guangzhou, P. R. China \\ * These authors have contributed equally to this work \\ Correspondence to: Lin-Zhong Yu, email: yulzh@smu.edu.cn \\ Keywords: Liang-Ge-San, inflammation, a7 nicotinic cholinergic receptor, NF-kB, Immunology and Microbiology Section, Immune \\ response, Immunity \\ Received: January 22, $2016 \quad$ Accepted: March 08, $2016 \quad$ Published: March 28, 2016
}

\section{ABSTRACT}

Liang-Ge-San (LGS) is a classic formula in traditional Chinese medicine, which is widely used to treat acute lung injury (ALI), pharyngitis and amygdalitis in clinic. However, the underlying mechanisms remain poorly defined. In this study, we discovered that LGS exerted potent anti-inflammatory effects in lipopolysaccharide (LPS)-induced inflammation. We found that LGS significantly depressed the production of IL-6 and TNF-a in LPS-stimulated RAW 264.7 macrophage cells. The degradation and phosphorylation of IKBa and the nuclear translocation of NF-KB p65 were also inhibited. Moreover, LGS activated a7 nicotinic cholinergic receptor ( $a 7 n A c h R)$. The blockage of a7nAchR by selective inhibitor methyllycaconitine (MLA) or a7nAchR siRNA attenuated the inhibitory effects of LGS on IKBa, NF-KB p65, IL-6 and TNF-a. Critically, LGS significantly inhibited inflammation in LPS-induced ALI rats through the activation of NF-KB signaling pathway. However, these protective effects could be counteracted by the treatment of MLA. Taken together, we first demonstrated anti-inflammatory effects of LGS both in vitro and in vivo through cholinergic antiinflammatory pathway. The study provides a rationale for the clinical application of LGS as an anti-inflammatory agent and supports the critical role of cholinergic antiinflammatory pathway in inflammation.

\section{INTRODUCTION}

The high mortality human diseases, such as acute lung injury (ALI), sepsis and shock, are caused by excessive inflammation [1-3]. Innate immune responses to the inflammation have been well delineated by humoral factors. However, recent research indicated that cholinergic anti-inflammatory pathway could significantly suppress peripheral inflammatory responses [4]. It potentially originates from activating the vagus nerve to release acetylcholine (Ach), which binds to the $\alpha 7$ cholinergic receptor $(\alpha 7 \mathrm{nAchR})$ on immune cells and then suppresses the production of inflammatory cytokines, including interleukin-6 (IL-6) and tumor necrosis factor (TNF- $\alpha$ ), high-mobility group box 1 proteins and matrix metalloproteinase 9 [5-9]. Studies have demonstrated that stimulating the vagus nerve could diminish the activation of macrophages in lethal sepsis rats and the cholinergic agonist nicotine could improve their survivals $[10,11]$. It has been also reported that the activation of cholinergic anti-inflammatory pathway could reduce ALI. a7nAchR agonist (nicotine, choline and PNU-282987) can suppress the excess lung water, reduce inflammatory cells, myeloperoxidase and proteins in the bronchoalveolar lavage fluid (BALF), and down-regulate pro-inflammatory chemokines and cytokines, including IL- $6, \mathrm{TNF}-\alpha$, macrophage inflammatory protein-1 $\alpha$ (MIP-1 $\alpha$ ) and macrophage inflammatory protein-2 (MIP-2) in LPS or acid-induced ALI murine model $[12,13]$.

Liang-Ge-San (LGS) is a classic Chinese medicine formula. This decoction was first described in "Taiping Huimin Heji Jufang", the pharmacopeia in Song dynasty. There are seven herbs, including Forsythiasuspense, Rheum palmatum, Scutellaria baicalensis, Gardenia 
jasminoides, Glycyrrhiza uralensis, Mentha haplocalyx and Natrii Sulfas in the formula. It has been widely used for centuries to clear heat and fire in traditional Chinese medicine. Nowadays, LGS exhibits curative effects on ALI, pharyngitis, amygdalitis and pneumonia $[14,15]$. In previous studies, we found that LGS could significantly inhibit the inflammation in LPS-induced ALI rats through suppressing the rise of wet-to-dry ratio of lung tissue and lung permeability. It could also decrease the helper T-cells (Th1-to-Th2) ratio in both of peripheral blood and BALF $[16,17]$. However, the underlying mechanisms remain poorly defined.

In this study, we first found that LGS exerted antiinflammatory effects via activating cholinergic antiinflammatory pathway, which led to the inhibition of NF$\kappa \mathrm{B}$ pathway in vitro and in vivo. Our research provided scientific evidence for the therapeutic application of LGS and supported the critical role of cholinergic antiinflammatory pathway in inflammation.

\section{RESULTS}

\section{Cytotoxicity of LGS in RAW 264.7 macrophage cells}

MTT assay was used to investigate the cytotoxicity of LGS in RAW 264.7 cells. Results showed that LGS (25 $\sim 400 \mu \mathrm{g} / \mathrm{ml}$ ) had no obvious effects on cell viability after $24 \mathrm{~h}$ treatment (Figure 1A). Furthermore, we evaluated the cell viability of LGS with LPS $(1 \mu \mathrm{g} / \mathrm{ml})$. It was found that both of LGS and LPS treatments didn't show significant cytotoxicity in RAW 264.7 cells (Figure 1B). Therefore, LGS at the concentrations of $25 \sim 400 \mu \mathrm{g} / \mathrm{ml}$ was selected in the subsequent experiments.

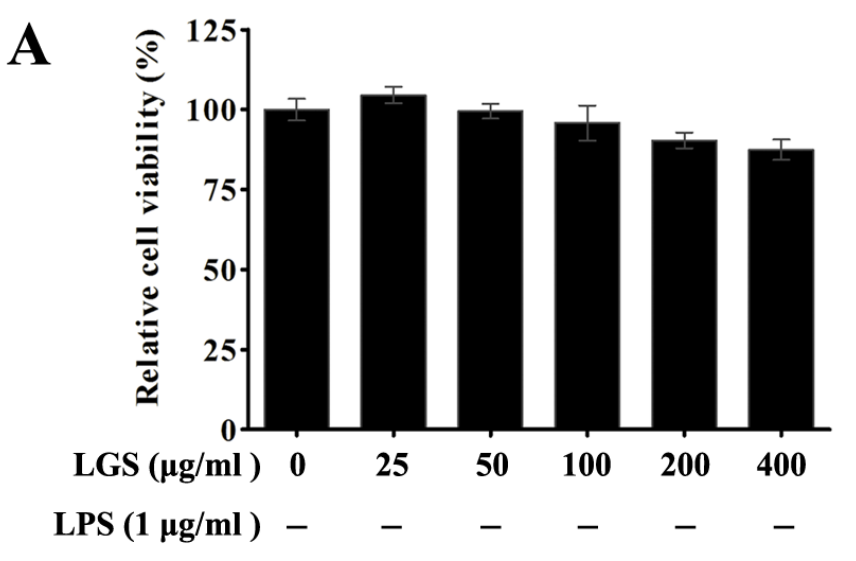

LGS inhibits the release of IL-6, TNF- $\alpha$ in RAW 264.7 macrophage cells

LPS-treated RAW 264.7 macrophage cells can produce pro-inflammatory cytokines IL- 6 and TNF- $\alpha$, which contribute to inflammation $[18,19]$. Hence, we detected the expressions of these cytokines. As shown in Figure 2, resting RAW 264.7 cells released little IL-6 (< $0.2 \mathrm{ng} / \mathrm{ml})$ and TNF- $\alpha(<1 \mathrm{ng} / \mathrm{ml})$. After stimulated by LPS, IL-6 (> $4.2 \mathrm{ng} / \mathrm{ml})$ and TNF- $\alpha(>4.5 \mathrm{ng} / \mathrm{ml})$ were significantly released from RAW 264.7 cells which were inhibited in the presence of LGS (Figure 2A \& 2B). It should be noticed that the inhibition of TNF- $\alpha$ was slightly attenuated when the concentration of LGS was exceeded $100 \mu \mathrm{g} / \mathrm{ml}$ (Figure 2B). This phenomenon might result from the hypo-toxic effect of LGS on RAW 264.7 cells. Collectively, these results suggest that LGS can inhibit inflammatory effects in LPS-stimulated RAW 264.7 macrophage cells.

\section{LGS attenuates NF- $\kappa B$ activation in LPS- stimulated RAW 264.7 macrophage cells}

In inflammatory responses, NF- $\mathrm{KB}$ is a critical transcriptional regulator for inflammatory-related gene coding [20]. Therefore, we hypothesized that the antiinflammatory effects of LGS might be associated with NF- $\kappa B$ pathway. To confirm this hypothesis, we observed the nuclear translocation of NF- $\mathrm{kB}$ p65 and the expression of $\mathrm{I} \kappa \mathrm{B} \alpha$, whose degradation and phosphorylation makes $\mathrm{NF}-\kappa \mathrm{B}$ p65 release and transfer into the nuclear [21]. Our results showed that LPS treatment induced the degradation and phosphorylation of IкB $\alpha$ in RAW 264.7 cells, while LGS treatment prevented this phenomenon (Figure 3A). In addition, we found that NF- $\mathrm{kB}$ p65 mainly existed in the

B

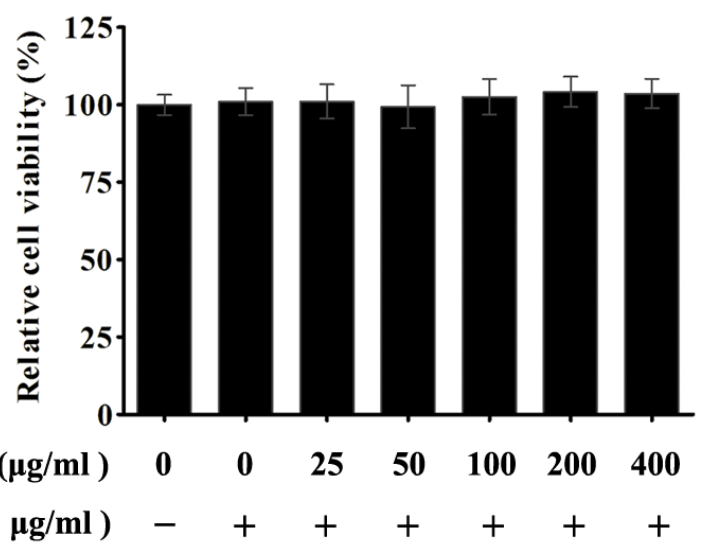

Figure 1: The cytotoxicity of LGS with or without LPS in RAW 264.7 macrophage cells. The viability was determined by MTT assay. A. Macrophages were incubated with LGS $(25 \sim 400 \mu \mathrm{g} / \mathrm{ml})$ alone for $24 \mathrm{~h}$. B. Macrophages were treated with LGS at different concentrations in the presence of LPS $(1 \mu \mathrm{g} / \mathrm{ml})$ for $24 \mathrm{~h}$. Data are represent as percentage of the cell viability as mean \pm S.D. of three independent experiments. 
cytoplasm of RAW 264.7 cells, which was transferred into nuclear after LPS stimulation. Notably, this migration was blocked in the presence of LGS $(400 \mu \mathrm{g} / \mathrm{ml})$ (Figure 3B). Finally, we confirmed the nuclear translocation of NF- $\kappa \mathrm{B}$ p65 by western blotting and EMSA, revealing that LGS suppressed endogenous NF- $\kappa \mathrm{B}$ p 65 nuclear translocation in LPS-stimulated RAW 264.7 cells (Figure 3C \& 3D). Taken together, these findings demonstrate that LGS attenuates inflammation by NF- $\kappa \mathrm{B}$ signaling pathway.

\section{LGS suppresses the inflammation and NF-кB pathway via the cholinergic anti-inflammatory pathway}

$\alpha 7 \mathrm{nAchR}$ expresses on macrophages and plays an important role in cholinergic anti-inflammatory pathway[9]. Previous studies have indicated that nicotine decreased the release of IL-6 and TNF- $\alpha$ via $\alpha 7 \mathrm{nAchR}$ in microphages $[5,22]$. Therefore, we detected that whether LGS could affect the expression of $\alpha 7 \mathrm{nAchR}$. As shown in Figure 4A, LGS increased the expression level of $\alpha 7 \mathrm{nAchR}$ in RAW 264.7 cells by western blotting, suggesting that LGS could activate the cholinergic antiinflammatory pathway.

We further explored the role of $\alpha 7 \mathrm{nAchR}$ in antiinflammatory effects of LGS. Special $\alpha 7 \mathrm{nAchR}$ siRNA (Figure 4B) or methyllycaconitine (MLA), a selective $\alpha 7 \mathrm{nAchR}$ inhibitor (Figure $4 \mathrm{C}$ ) was used to abrogate this protein. The results showed that the decrease of $\alpha 7 \mathrm{nAchR}$ counteracted the inhibitory effects of LGS on the degradation and phosphorylation of $\mathrm{I} \kappa \mathrm{B} \alpha$ and the nuclear translocation of NF- $\kappa \mathrm{B}$ in LPS-stimulated RAW 264.7 cells. Moreover, the inhibition of $\alpha 7 \mathrm{nAchR}$ could also decrease the suppressive effects of LGS on the levels of IL-6 and TNF- $\alpha$ (Figure 4D). These data demonstrate that LGS inhibits inflammation and NF- $\kappa B$ pathway which is associated with the activation of cholinergic antiinflammatory pathway.

\section{LGS attenuates inflammation in ALI rats through cholinergic anti-inflammatory pathway}

Previous studies have elucidated that nicotine could reduce inflammatory response in LPS-induced ALI murine model and LGS could protect against LPS-induced ALI rats $[12,16]$. Therefore, we detected that whether LGS could prevent ALI through cholinergic anti-inflammatory pathway in vivo. As shown in Figure 5A, LGS decreased hyperaemia and swelling on the pulmonary surface in LPS-induced ALI rats dose-dependently. The same phenomena were also observed in the species after a selective $\alpha 7 \mathrm{nAChR}$ agonist PNU282987 (PNU) treatment. It should be pointed out that the characteristic of the pulmonary surface after HLGS treatment was like that after PNU treatment, implying the significant protective activity of LGS. However, the anti-ALI effects of LGS can be counteracted in the presence of MLA. Lung pathologic observation also showed that MLA suppressed the ameliorated effects of LGS on edema, hyperaemia and neutrophil infiltration (Figure 5B). Acetyl cholinesterase (AchE) is the necessary hydrolytic enzyme for acetyl choline in cholinergic anti-inflammatory pathway. Indeed, we noticed that LGS inhibited the activity of acetyl cholinesterase (Figure 5C), indicating that LGS attenuates acetyl choline hydrolyzation. These data together demonstrate that LGS inhibits LPS-induced ALI through cholinergic anti-inflammatory pathway.

Lung type II alveolar cell is regard as the protective barrier of lung and osmilphilic multilamellar body is a key structure in the type II alveolar cell to maintain cellular homeostasis $[23,24]$. As shown in Figure 6A, normal lung type II alveolar cell (blue arrow) was exerted in the
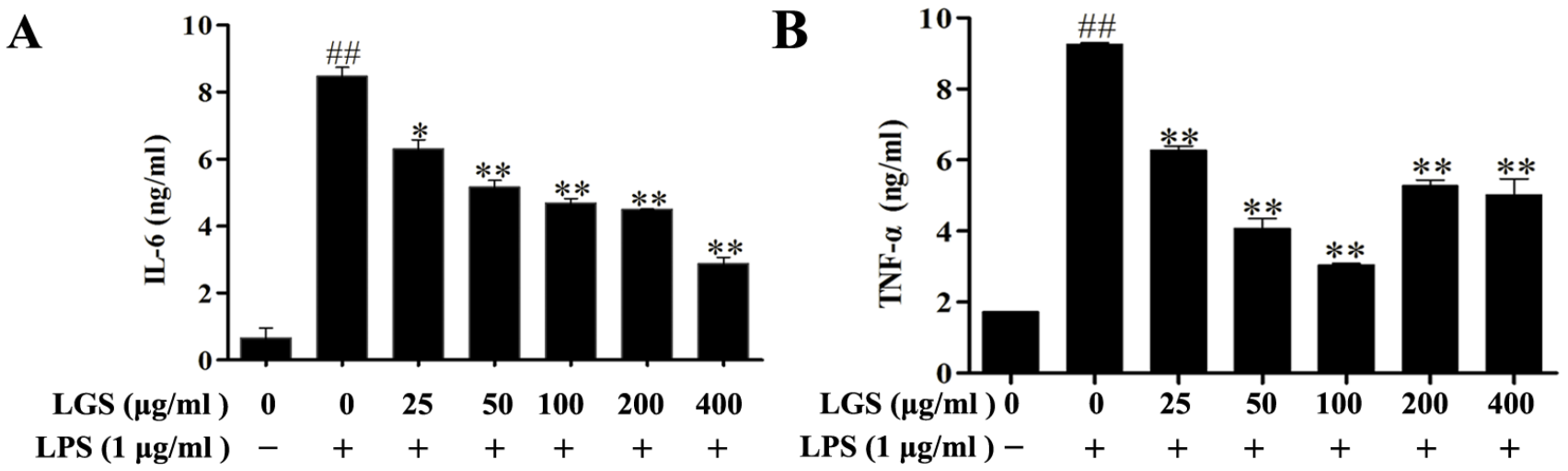

Figure 2: LGS attenuates the production of IL-6 and TNF- $\alpha$ in LPS-stimulated RAW 264.7 cells. RAW 264.7 cells were cultured with indicated concentrations of LGS in the presence or absence of LPS (1 $\mu \mathrm{g} / \mathrm{ml})$ for $24 \mathrm{~h}$. Quantitative analyses of IL-6 A. and TNF- $\alpha$ B. in supernatants of macrophages were measured by ELISA. ${ }^{\# \#} P<0.01$ versus control, ${ }^{*} P<0.05$ and ${ }^{* *} P<0.01$ versus LPS treatment, one-way ANOVA, post hoc comparisons, Turkey, Cloumns, mean; error bar, S.D. 
A LPS $(1 \mu \mathrm{g} / \mathrm{ml}) \quad-\quad+\quad+\quad+\quad+\quad+\quad+$

$\begin{array}{llllllll}\text { LGS }(\mu \mathrm{g} / \mathrm{ml}) & 0 & 0 & 25 & 50 & 100 & 200 & 400\end{array}$

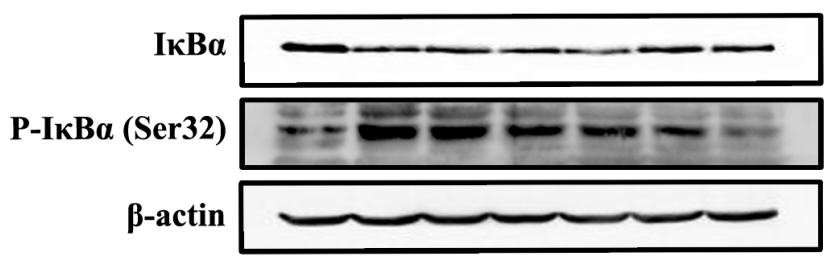

B
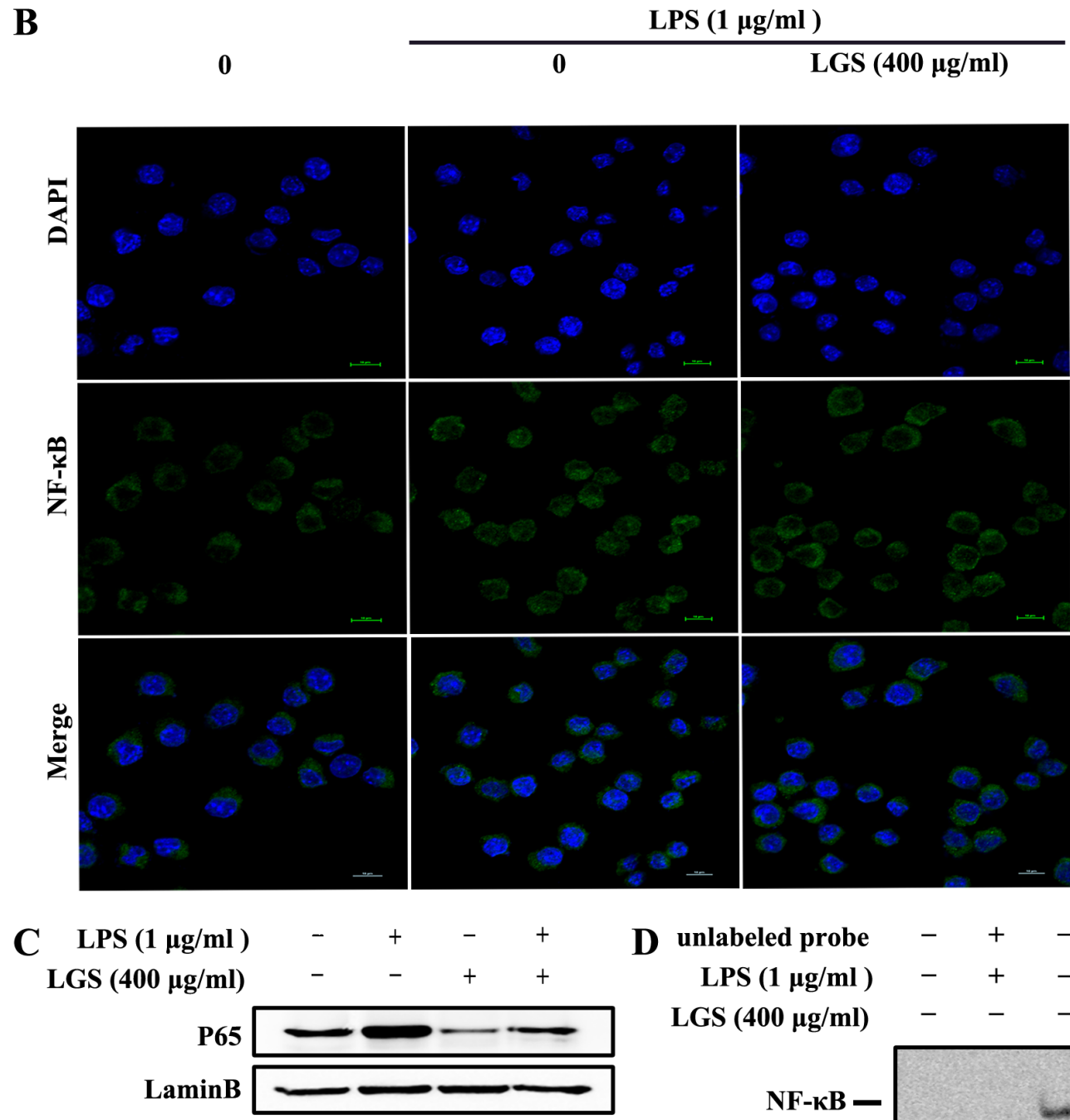
D unlabeled probe $\quad-\quad+\quad-\quad-\quad-\quad-$ $\operatorname{LPS}(1 \mu \mathrm{g} / \mathrm{ml})-+-\quad+-+$ LGS $(400 \mu \mathrm{g} / \mathrm{ml}) \quad-\quad-\quad-\quad+\quad+\quad+$

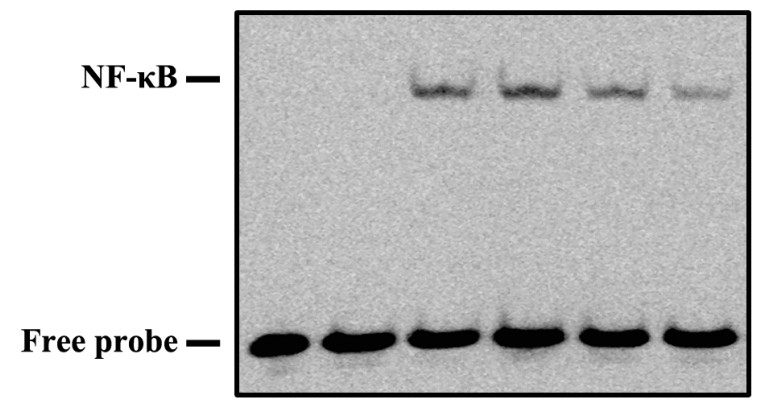

Figure 3: LGS inhibits the activation of NF-KB signaling in LPS-stimulated RAW 264.7 cells. A. LGS suppresses LPSinduced degradation and phosphorylation of IKB $\alpha$. RAW 264.7 cells were stimulated with LPS $(1 \mu \mathrm{g} / \mathrm{ml})$ for $30 \mathrm{~min}$ and then treated with different concentrations of LGS for $24 \mathrm{~h}$. The expression levels of I $\mathrm{I} B \alpha$ and $\mathrm{p}-\mathrm{I} \mathrm{I} B \alpha(\mathrm{Ser} 32)$ were examined by western blotting. B.-D. LGS blocks NF-kB p65 translocation from cytoplasm to nuclear. RAW 264.7 cells were stimulated with LPS (1 $\mu \mathrm{g} / \mathrm{ml})$ for $2 \mathrm{~h}$, incubated with or without LGS $(400 \mu \mathrm{g} / \mathrm{ml})$ for $24 \mathrm{~h}$ and observed by confocal microscopy. $(200 \times)(\mathrm{B})$. Expression of NF-kB p65 in nuclear was detected by western blotting (C) and NF-kB nuclear binding activity was measured by EMSA (D). 
CON and LGS groups. Osmilphilic multilamellar body (yellow arrow) was excluded from lung type II alveolar cells in the LPS group and the lung type II alveolar cell (black arrow) was removed from the basement membrane in the MLA group, indicating the destroy of lung type II alveolar cells. It also found that inflammatory cells (red arrow) were existed in alveolar spaces in the LPS group. However, after LGS treatment, inflammatory cells were decreased and the damage on lung type II alveolar cells was inhibited, suggesting that LGS can suppress edema

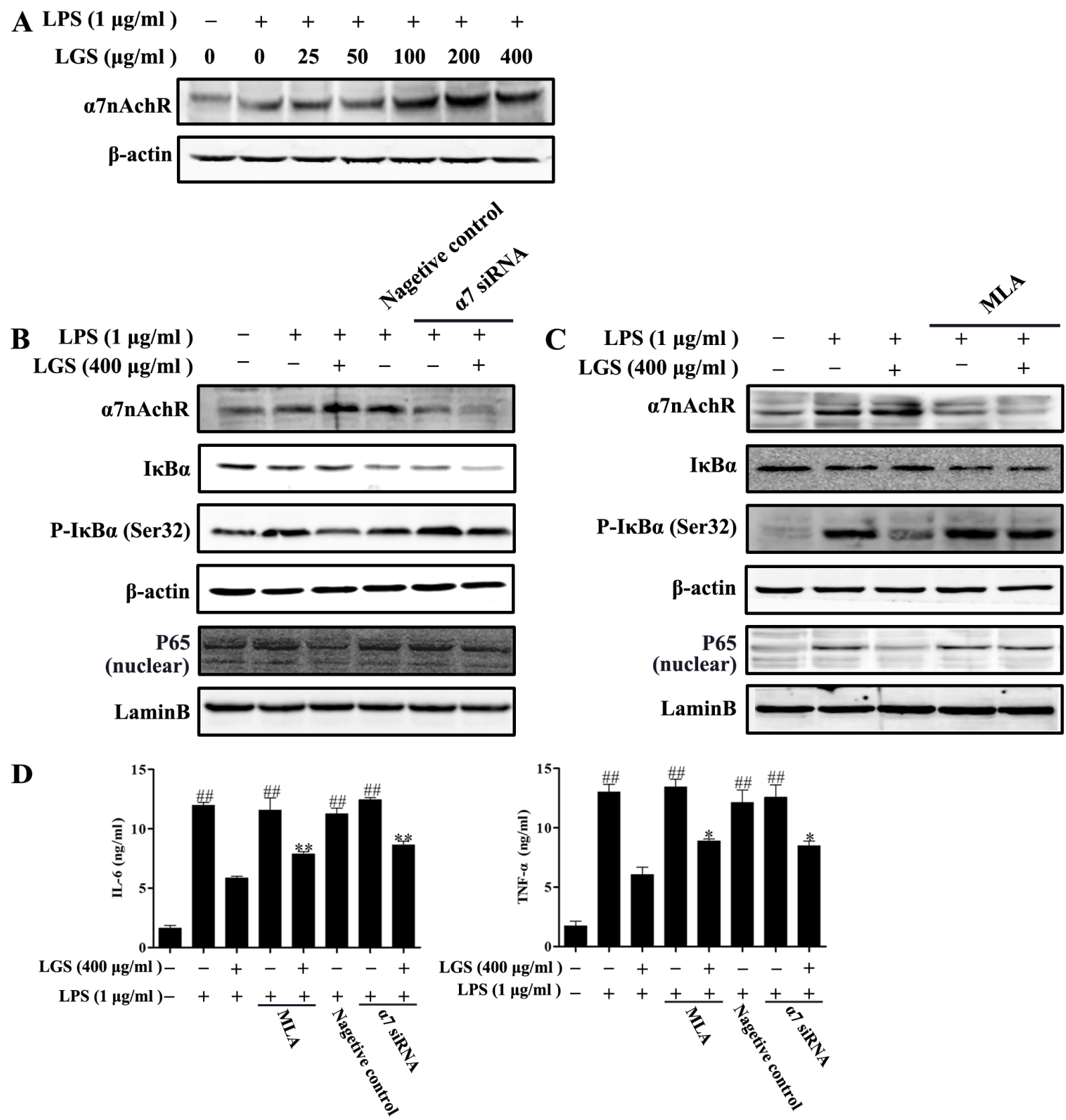

Figure 4: LGS suppresses inflammation and NF-кB pathway via $\boldsymbol{\alpha} \mathbf{7 n A c h R}$ activation. A. LGS increases the expression of $\alpha 7 \mathrm{nAchR}$. RAW 264.7 cells were pretreated with indicated concentrations of LGS for $24 \mathrm{~h}$ and then stimulated with LPS (1 $\mu \mathrm{g} / \mathrm{ml})$ for $2 \mathrm{~h}$. The level of $\alpha 7 \mathrm{nAchR}$ in total lysate was evaluated by western blotting. B.-C. LGS suppresses NF-kB pathway via $\alpha 7 \mathrm{nAchR}$. RAW 264.7 cells were transfected with $\alpha 7 \mathrm{nAchR}$ siRNA $(120 \mathrm{nM})$ for $24 \mathrm{~h}(\mathrm{~B})$ or treated with methyllycaconitine (MLA, $20 \mu \mathrm{M})$ for $2 \mathrm{~h}(\mathrm{C})$ before cultured with $400 \mu \mathrm{g} / \mathrm{ml} \mathrm{LGS}$ for $24 \mathrm{~h}$ and then stimulated with LPS $(1 \mu \mathrm{g} / \mathrm{ml})$ for $30 \mathrm{~min}$ or $2 \mathrm{~h}$. The levels of $\alpha 7 \mathrm{nAchR}$ (for $2 \mathrm{~h}$ ), IкB $\alpha$

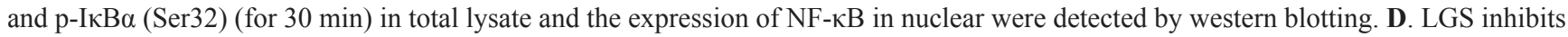
the production of IL- 6 and TNF- $\alpha$ via $\alpha 7 \mathrm{nAchR}$. RAW 264.7 cells were transfected with $\alpha 7 \mathrm{nAchR}$ siRNA (120 nM) for $24 \mathrm{~h}$ or pretreated with MLA $(20 \mu \mathrm{M})$ for $2 \mathrm{~h}$ before culturing with LGS $(400 \mu \mathrm{g} / \mathrm{ml})$ in the presence or absence of LPS (1 $\mu \mathrm{g} / \mathrm{ml})$ for $24 \mathrm{~h}$. IL-6 (left panel) and TNF- $\alpha$ (right panel) in the supernatants were determined by ELISA. ${ }^{\# \#} P<0.01$ versus control, ${ }^{*} P<0.05$ and ${ }^{* *} P<0.01$ versus LGS and LPS treatment, one-way ANOVA, post hoc comparisons, Turkey, Cloumns, mean; error bar, S.D. 
and inflammation. Moreover, LGS could down-regulate the oedematous indicators, including lung W/D ratio (Figure 6B), total protein (Figure 6C), total cells (Figure $6 \mathrm{D}$ ) and neutrophils (Figure 6E) which were similar as
PNU treatment. In addition, LGS attenuated inflammatoryassociated factors, such as MPO, MIP- $1 \alpha$, MIP- 2, TNF- $\alpha$ and IL-6 in BALF in LPS-induced ALI (Figure 6F). However, these effects of LGS could be counteracted

A
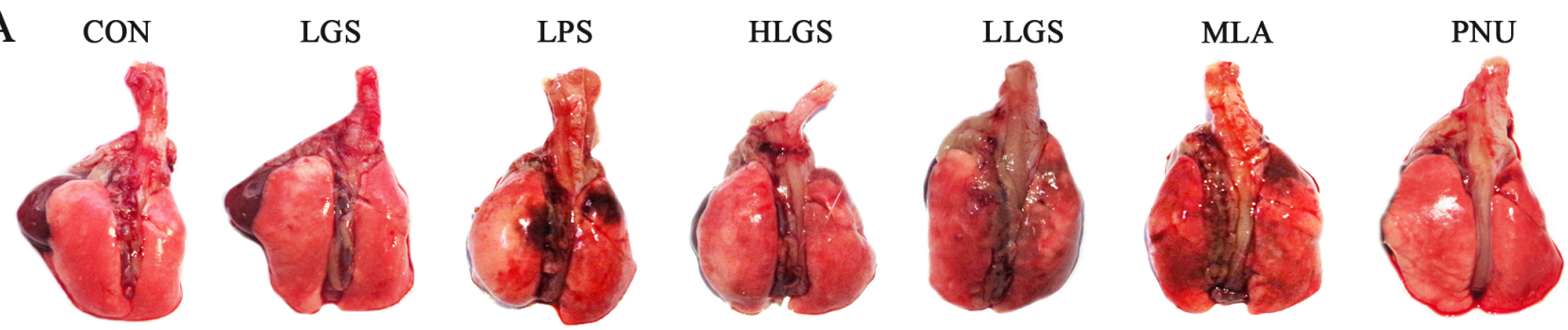

B
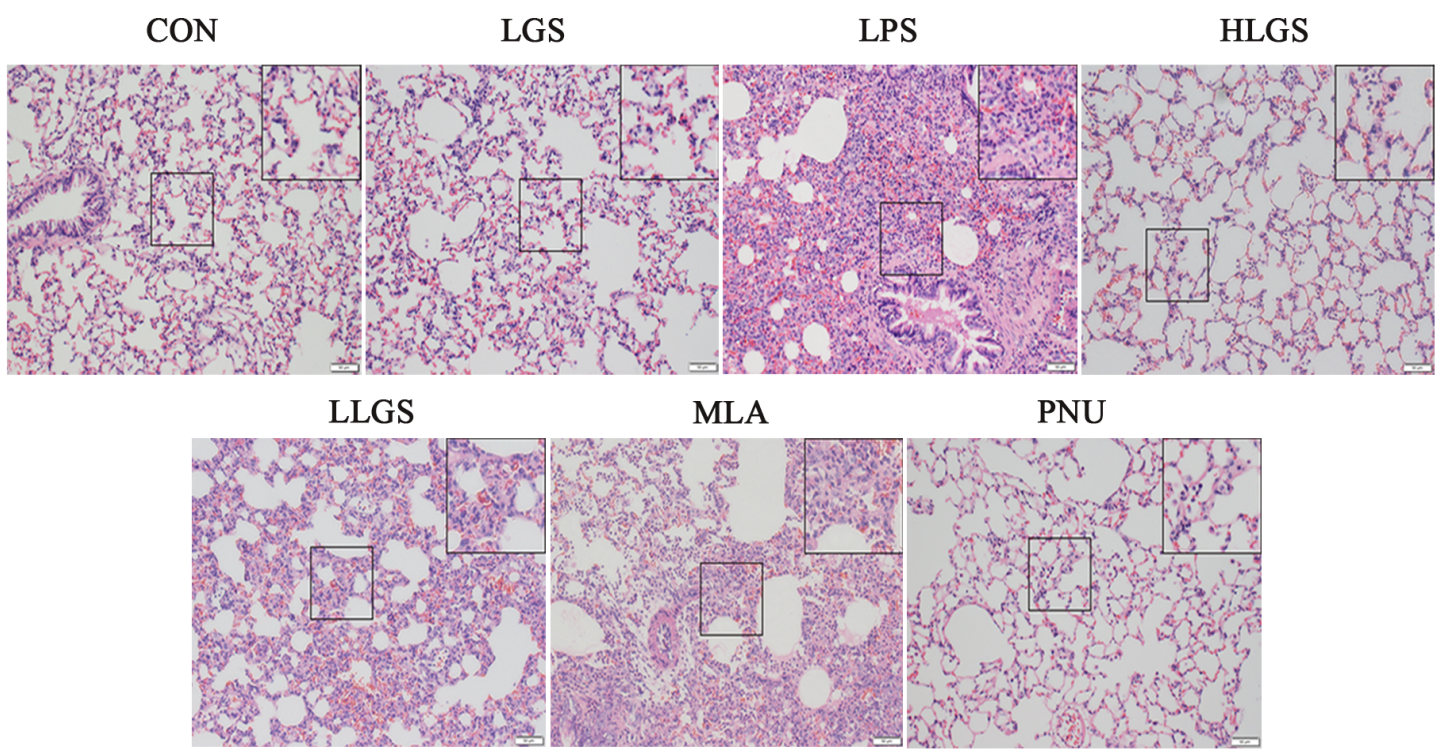

MLA

PNU
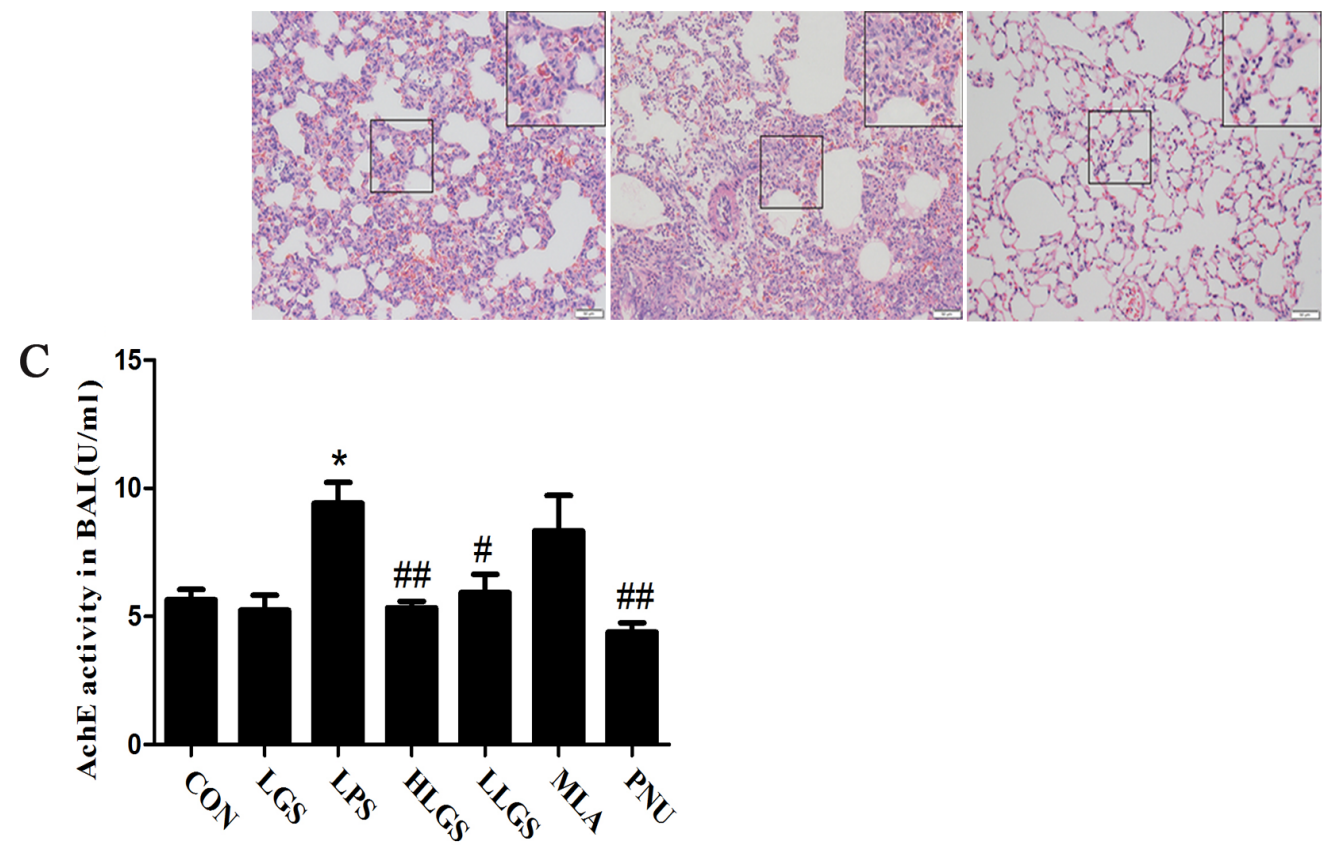

Figure 5: LGS attenuates LPS-induced acute lung injury (ALI) through cholinergic anti-inflammatory pathway. LGS with or without methyllycaconitine (MLA, a $\alpha 7 \mathrm{nAchR}$ selective inhibitor) were treated with LPS-induced ALI rats. PNU282987 (PNU), a highly selective AChR $\alpha 7$ agonist, was used as a positive control. A. LGS decreases hyperaemia and swelling on the pulmonary surface in LPS-induced ALI rats which can be counteracted in the appearance of MLA. At $8 \mathrm{~h}$ after ALI, the rats were sacrificed and the representative lungs removed were photographed. B. MLA attenuates the influence of LGS on lung histopathological changes in LPS-induced ALI rats. Lungs were fixated. After paraffin embedding and sectioning at $5 \mu \mathrm{m}$ thickness, lung tissues were stained by hematoxilin and eosin (H\&E) staining. $(200 \times)$ C. MLA counteracts the inhibitory effects of LGS on Acetyl cholinesterase (AChE) in LPS-induced ALI rats. At 8 h after ALI, the rats were sacrificed and the bronchoalveolar lavage fluid (BALF) was obtained. The activity of AChE in supernatants of BALF samples was measured using acetyl cholinesterase kit according to the manufacturer's protocol. ${ }^{*} P<0.05$ versus control, ${ }^{\#} P<0.05$ and ${ }^{\#} P<0.01$ versus LPS, one-way ANOVA, post hoc comparisons, Turkey, Cloumns, mean; error bar, S.D. 
A

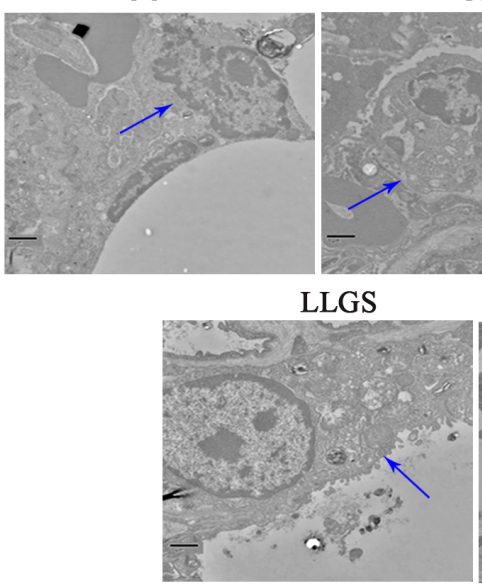

LGS

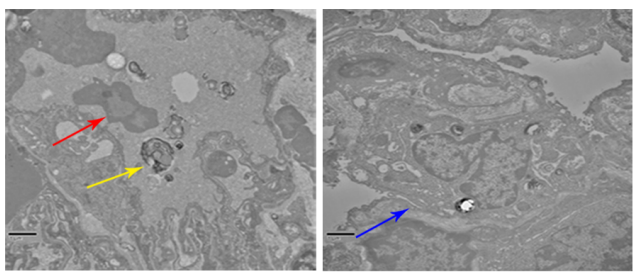

HLGS
PNU

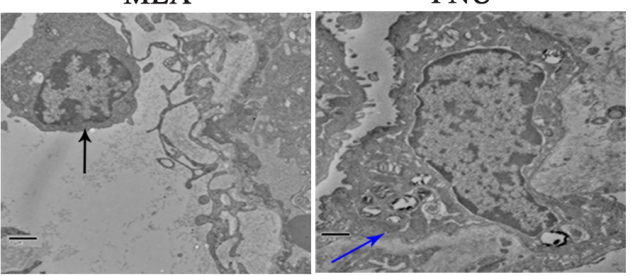

B

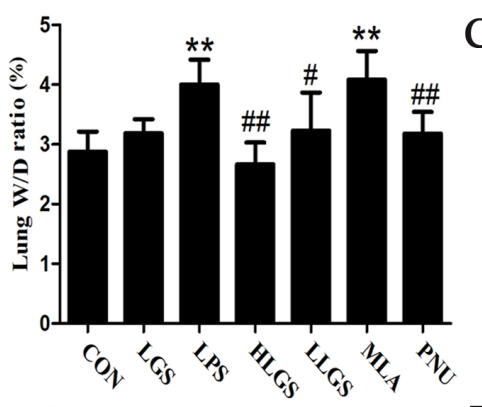

$\mathrm{E}$
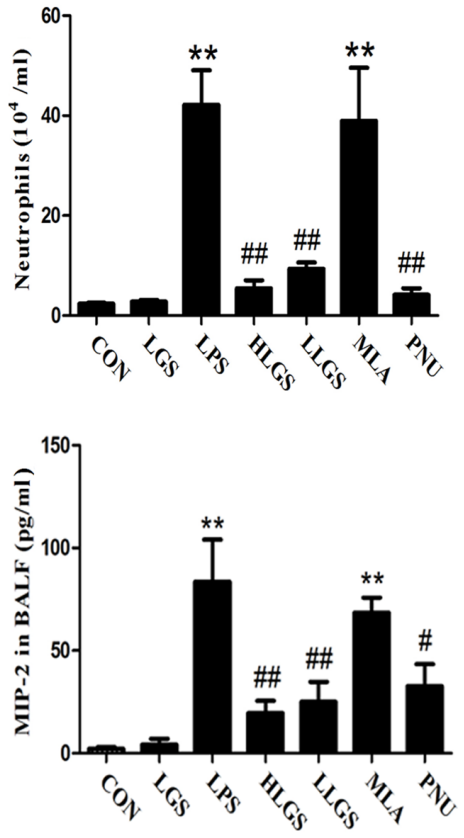
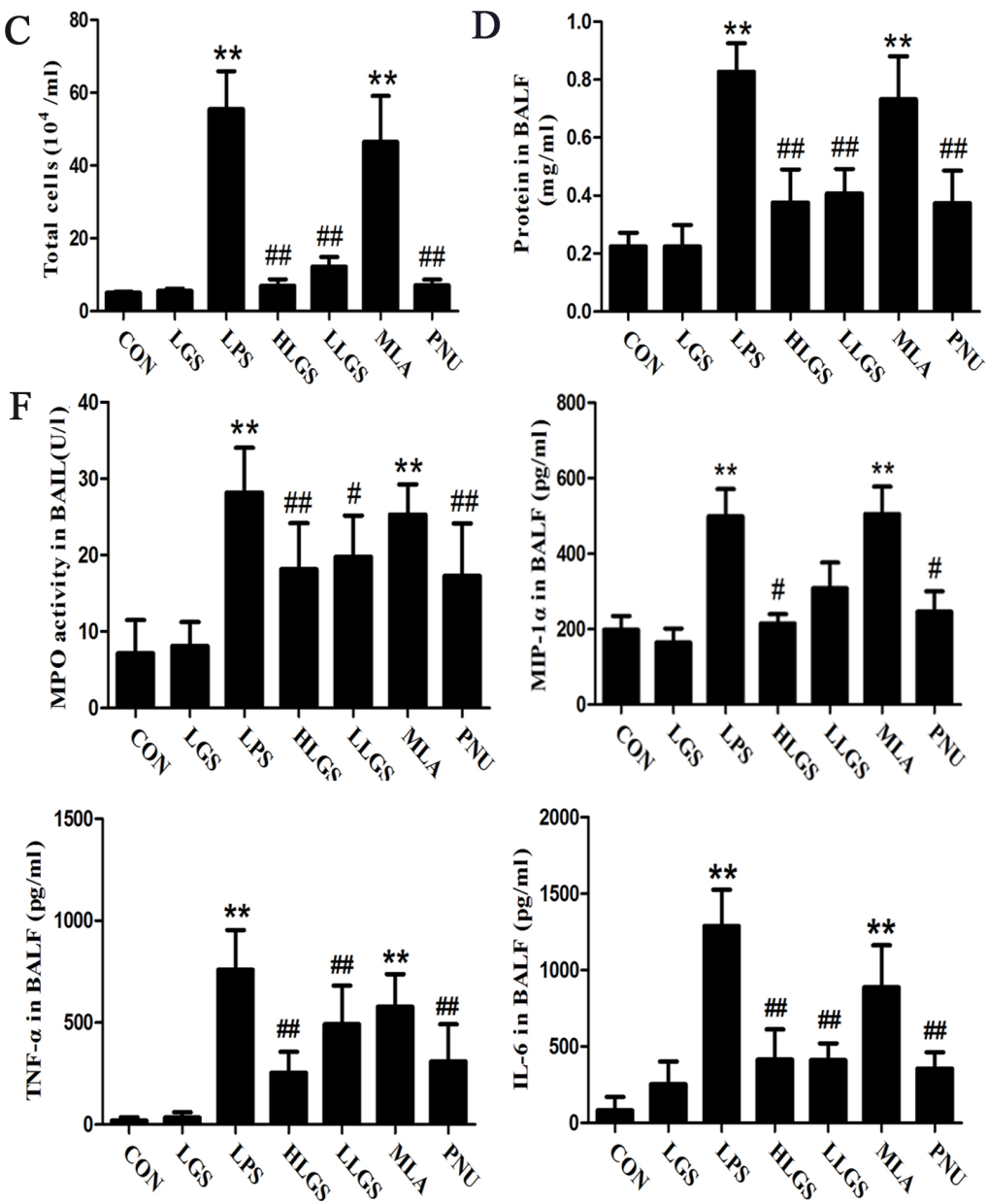

Figure 6: LGS inhibits edema and inflammation in LPS-induced ALI rats through cholinergic anti-inflammatory pathway. LGS with or without methyllycaconitine (MLA, a $\alpha 7 \mathrm{nAchR}$ selective inhibitor) were treated with LPS-induced ALI rats. PNU282987 (PNU), a highly selective AChR $\alpha 7$ agonist, was used as a positive control. A. MLA attenuates the influence of LGS on lung ultrastructural changes in LPS-induced ALI rats. Ultrastructures of lung tissues were observed by transmission electron microscopy (15 000 $\times$, Blue arrow, normal lung type II alveolar cell; Red arrow, inflammatory cell in alveolar spaces; Yellow arrow, osmilphilic multilamellar body in alveolar spaces; Black arrow, lung type II alveolar cell in alveolar spaces). B. MLA reduces the decrease of the ratio of lung wet weight (W) and dry weight (D) induced by LGS in ALI rats. At $8 \mathrm{~h}$ after ALI, lungs were separated, and weighing to get the lung W/D ratio. BALF was obtained after the sacrifice of rats to calculate the total protein concentration (C), total cells count (D) and neutrophils count (E). F. MLA attenuates the regulatory activity of LGS on inflammatory factors. After rats were sacrificed, the BALF was obtained to measure the levels of MPO, MIP-1 $\alpha$, MIP-2, TNF- $\alpha$ and IL-6 by ELISA. ${ }^{* *} P<0.01$ versus control, ${ }^{\#} P<0.05$, and ${ }^{\# \#} P<0.01$ versus LPS, one-way ANOVA, post hoc comparisons, Turkey, Cloumns, mean; error bar, S.D. 
by MLA. Taken together, our results indicate that LGS suppresses edema and inflammation in LPS-induced ALI rats through cholinergic anti-inflammatory pathway.

We further analyzed the expression of $\mathrm{I} \kappa \mathrm{B} \alpha$ and nuclear translocation of NF- $\mathrm{KB}$ p65 in ALI rats. As shown in Figure 7A, LGS suppressed the degradation and phosphorylation of I $\mathrm{I} B \alpha$ while MLA treatment counteracted this phenomenon. MLA also attenuated the inhibitory effects of LGS on the translocation of NF$\kappa \mathrm{B}$ p65 from cytoplasm to nuclear (Figure 7B). Similar results were observed by immunohistochemistry (Figure 7C). These results reveal that LGS inhibits the activation of NF- $\mathrm{BB}$ pathway in LPS-induced ALI rats through cholinergic anti-inflammatory pathway.

\section{DISCUSSION}

Acute lung injury (ALI) is an acute respiratory failure disease with high mortality rate of $40 \sim 60$ $\%$, resulting from many severe diseases, such as sepsis pneumonia and acid aspiration [25]. Until now, effective therapeutic schedule with less side-effect has not available. The characteristics of ALI include noncardiogenic pulmonary edema, hypoxemia, neutrophil infiltration and disrupted lung mechanics which are related to inflammation [26-28]. Accordingly, the inhibition of inflammatory response is pivotal in the progression of ALI. Clinical observation found that LGS could depress ALI [15]. Here we showed that LGS not only suppressed

A

\section{CON LGS LPS HLGS LLGS MLA PNU}

$\mathrm{I} \kappa \mathrm{B} \alpha$

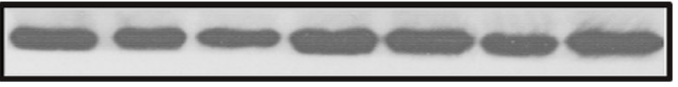

$\mathrm{P}-\mathrm{I} \kappa \mathrm{B} \alpha(\operatorname{Ser} 32)$

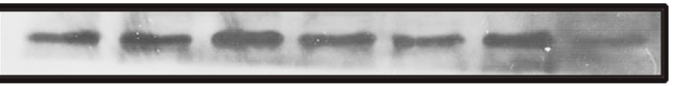

$\beta$-actin

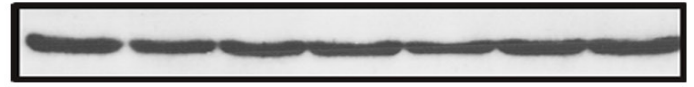

B

\section{CON LGS LPS HLGS LLGS MLA PNU}

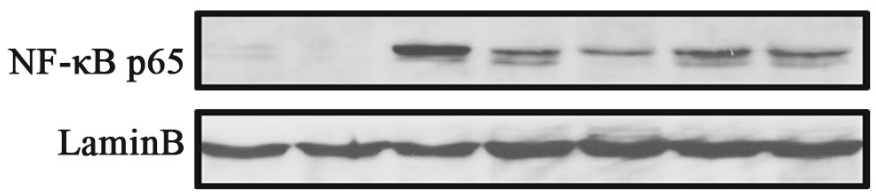

C

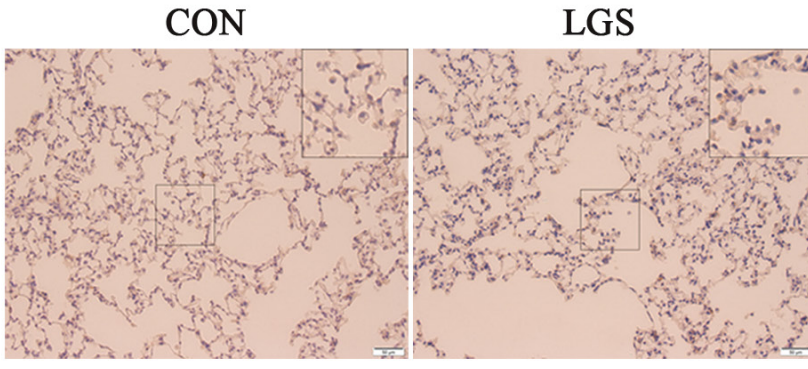

LLGS

MLA
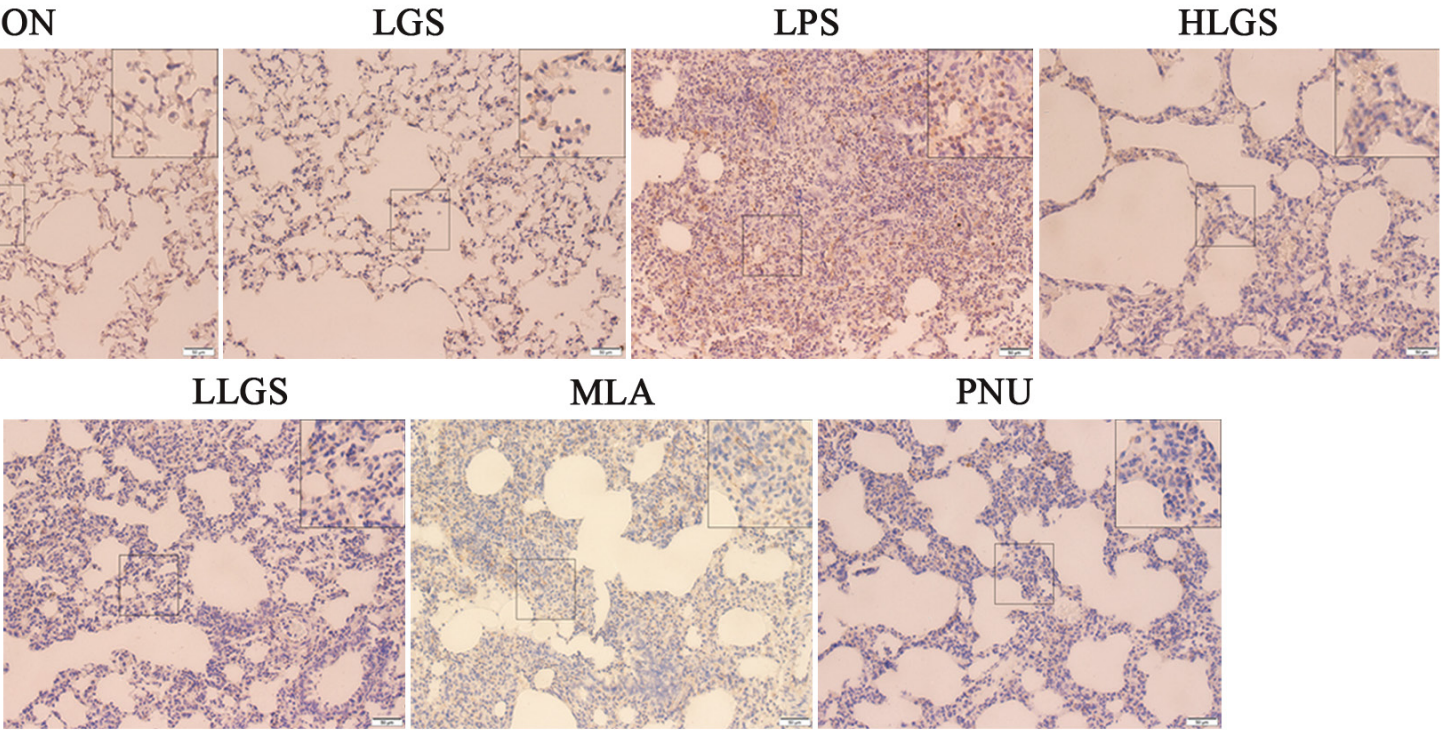

PNU

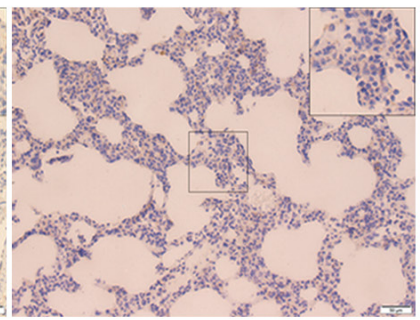

Figure 7: LGS inhibits the activation of NF-кB pathway in LPS-induced ALI rats through cholinergic anti-inflammatory pathway. A. MLA counteracts the inhibitory effects of LGS on the degradation and phosphorylation of I $\mathrm{B} \alpha$ in LPS-induced ALI rats. The lung tissues were removed and homogenated after the sacrifice of rats. The total protein was used to detect the expressions of I $\mathrm{K} \alpha \boldsymbol{\alpha}$ and $\mathrm{p}-\mathrm{I} \kappa \mathrm{B} \alpha(\mathrm{Ser} 32)$ by western blotting. B.-C. MLA attenuates the inhibitory effects of LGS on the translocation of NF- $\kappa \mathrm{B}$ p65 from cytoplasm to nuclear. The lung tissues were removed and homogenated after the sacrifice of rats. The nuclear protein was used to detect the expression of NF- $\kappa$ B p 65 by western blotting (B). Lungs were fixated, embeded in paraffin and sectioned at $5 \mu \mathrm{m}$ thickness. Lung sections were stained by immunohistochemistry (C). 
LPS-stimulated inflammation in vitro, but also inhibited LPS-induced ALI in vivo.

The nuclear transcription factor $N F-\kappa B$ is a potential positive regulator to stimulate the release of proinflammatory cytokines in inflammation [29]. Our present data indicated that LGS suppressed the degradation and phosphorylation of $\mathrm{I} \kappa \mathrm{B} \alpha$ and the transactivational activity of NF- $\mathrm{B}$ p 65 in LPS-stimulated cell and rat models, suggesting that NF- $\kappa \mathrm{B}$ pathway was involved in the antiinflammatory effects of LGS.

Cholinergic anti-inflammatory pathway has been well known as a central nervous system suppressing peripheral inflammatory responses. There is a family of nicotinic acetylcholine receptors in this pathway and 16 different subunits have been identified, including $\alpha 1-7, \alpha$ 9-10, $\beta$ 1-4, $\gamma, \delta$ and $\varepsilon$ [30-32]. Among them, $\alpha 7$ subtype expresses on macrophages and plays an important role in cholinergic anti-inflammatory pathway [5]. Studies in animal-models under the experimental conditions of sepsis, shock, or in rheumatoid arthritis patients have demonstrated that nicotine could inhibit the production of pro-inflammatory cytokines through $\alpha 7 \mathrm{nAchR}[5,6$, $33,34]$. In present study, we found that LGS stimulated the expression of $\alpha 7 \mathrm{nAchR}$ in LPS-induced macrophage cells and inflammatory responses were attenuated after $\alpha 7 \mathrm{nAchR}$ abrogation, similar to previous research [22]. These data suggested that cholinergic anti-inflammatory pathway play a pivotal role in the anti-inflammatory effects of LGS in vitro and in vivo.

It has been indicated that the activation of cholinergic anti-inflammatory pathway involved in the suppression of NF- $\kappa \mathrm{B}$ p 65 pathway. In LPS-stimulated inflammation, the selective cholinergic agonist nicotine inhibited phosphorylation of $\mathrm{I} \kappa \mathrm{B} \alpha$ and the transactivational activity of NF- $\kappa \mathrm{B}$ to exert anti-inflammatory effects $[6,35,36]$. Similarly, MLA could block the inhibitory effects on TNF- $\alpha$ expression and NF- $\kappa \mathrm{B}$ translocation stimulated by Ach in LPS-induced in Caco-2 cells [37]. We noticed that the inhibition of $\alpha 7 \mathrm{nAchR}$ could block the degradation and phosphorylation of $\mathrm{I} \kappa \mathrm{B} \alpha$ and the nuclear translation activity of NF- $\mathrm{B}$ p 65 induced by LGS. Our data implied that the activation of cholinergic antiinflammatory pathway inhibited NF- $\mathrm{B}$ pathway in the anti-inflammatory effects of LGS.

In summary, we first found that LGS has significantly anti-inflammatory effects in vitro and in vivo. We elucidated the underlying mechanism that involves stimulating $\alpha 7 \mathrm{nAchR}$ to suppress $\mathrm{NF}-\kappa \mathrm{B}$ pathway (Figure 8). Our study provides a rationale for the clinical application of LGS as an anti-inflammatory agent and

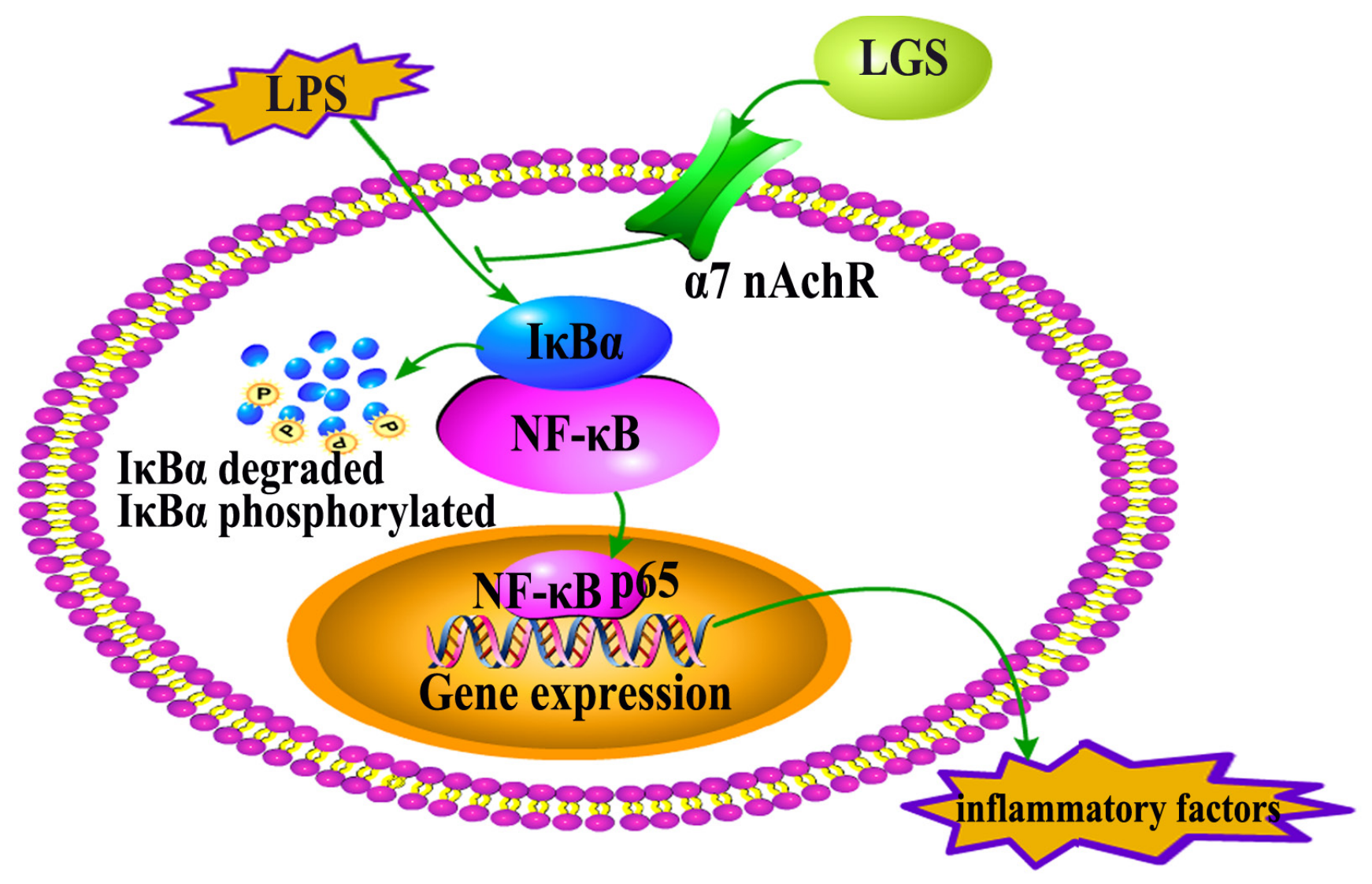

Figure 8: The speculated anti-inflammatory network of LGS. $\perp$ indicates an inhibitory effect. LGS exerts anti-inflammatory

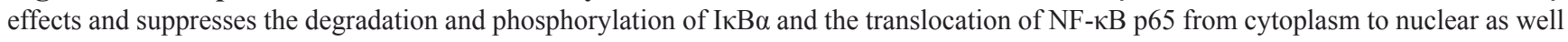
as the release of inflammatory factors induced by LPS through cholinergic anti-inflammatory pathway in vitro and in vivo. 
supports the critical role of cholinergic anti-inflammatory pathway in inflammation, especially $\alpha 7 \mathrm{nAchR}$ as an important anti-inflammatory target. However, LGS is a formula with multiple components, which inevitably leads to the complexity of pharmacological effects and molecular mechanisms. Therefore, to explore the specific anti-inflammatory component(s) of LGS is urgently needed.

\section{MATERIALS AND METHODS}

\section{Reagents}

The herbs, Forsythia suspense (Thunb.) Vahl, Rheum palmatum L., Scutellaria baicalensis Georgi, Gardenia jasminoides Ellis., Glycyrrhiza uralensis Fisch., Mentha haplocalyx Briq. and Natrii Sulfas. were purchased from Kangmei (Guangzhou, China). Antibodies against NF- $\kappa \mathrm{B}$

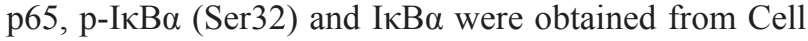
Signaling Technology (Danvers, MA). LaminB, $\beta$-actin and $\alpha 7 \mathrm{nAchR}$ antibodies were from Santa Cruz (Santa Cruz, CA). Alexa Fluor 488 secondary antibody and Lipofectamine 3000 transfection reagent were purchased from Invitrogen (Grand Island, NY). IL-6 and TNF- $\alpha$ ELISA kits were obtained from Dakewei (Beijing, China). Myeloperoxidase (MPO) and acetyl cholinesterase kits were purchased from Nanjing Jiancheng Bioengineering Institute (Nanjing, China) and DAB substrate kit was from Solarbio science \& technology (Beijing, China) and $\alpha 7$ AAchR small interfering RNA (siRNA) kit was from GenePharma (Shanghai, China). Nuclear and cytoplasmic protein extraction kit was purchased from Beyotime (Jiangsu, China). BCA protein assay kit and LightShift chemiluminescent EMSA kit were from Thermo Scientific (Rockford, IL). All the other reagents were purchased from Sigma Chemicals (St. Louis, MO).

LGS was prepared as described before and fingerprint analysis was performed by HPLC-DAD [38]. The freeze-dried power of LGS was dissolved in DMEM at a concentration of $20 \mathrm{mg} / \mathrm{ml}$ and stored at $-20{ }^{\circ} \mathrm{C}$.

\section{Animals}

Male Wistar rats $(180-220 \mathrm{~g}), 6-8$ weeks old, were purchased from the Center of Experimental Animals of Southern Medical University (Guangzhou, Guangdong, China). The rats were housed in climate-controlled quarters $\left(22-26{ }^{\circ} \mathrm{C}\right.$ at $40-70 \%$ humidity $)$ with a $12 \mathrm{~h}$ light/dark cycle and free access to food and water. All experiments were performed in accordance with the National Institutes of Health guide for the care and use of laboratory animals approved by the ethical committee for the experimental use of animals at Southern Medical University (2015-002).

\section{Grouping and Modeling}

Fifty-six rats were randomly divided into seven groups ( $\mathrm{n}=8 /$ group): control $(\mathrm{CON})$, LGS, LPS, high dose of LGS (HLGS), low dose of LGS (LLGS), methyllycaconitine (MLA, a $\alpha 7 \mathrm{nAchR}$ selective inhibitor) and PNU282987 (PNU, a selective $\alpha 7 \mathrm{nAChR}$ agonist). Group CON was received normal saline $(1 \mathrm{ml} /$ day intragastric) as the vehicle control and group LGS was treated with LGS (30 g/kg/day intragastric). Group HLGS and group LLGS were administered with a high dosage of LGS (30 g/ $/ \mathrm{kg} /$ day intragastric) or low dosage of LGS (7.5 g/kg/day intragastric) [4]. Group MLA was received MLA (3 mg/kg/day intravenous) for $10 \mathrm{~min}$ before LGS intragastrical administration (30 g/kg/day) [19]. Group PNU was treated with PNU ( $2.4 \mathrm{mg} / \mathrm{kg}$ intraperitoneal) once for $20 \mathrm{~min}$ before the intratracheal instillation of LPS [13]. After 5 days, all groups except group CON and LGS were treated with of LPS $(5 \mathrm{mg} / \mathrm{kg}$, intratracheal) to replicate the experimental model of ALI [18]. The rats were anesthetized with $10 \%(w / v)$ pentobarbital sodium solution to obtain BALF samples and lung tissues were removed after sacrifice for further experiments

\section{Cell Culture}

Murine macrophage cell line RAW 264.7 was purchased from Cell Bank of the Chinese Academy of Sciences (Shanghai, China). Cells were cultured in DMEM containing $10 \%(v / v)$ fetal bovine serum (invitrogen) and $1 \%(v / v)$ penicillin/streptomycin (Gibco) at $37{ }^{\circ} \mathrm{C}$ in a humidified incubator with $5 \% \mathrm{CO}_{2}$.

\section{Cell viability assay}

Cell viability assay was performed by 3-(4, 5-dimethylthiazol-2-yl)-2, 5-diphenyltetrazolium bromide (MTT) assay. RAW 264.7 cells were cultured in a 96-well plate with the density of $5 \times 10^{4}$ cells $/ \mathrm{ml}$ for $24 \mathrm{~h}$. Then, cells were treated with various concentrations of LGS in the presence or absence of LPS $(1 \mu \mathrm{g} / \mathrm{ml})$ for another 24 h. $30 \mu \mathrm{l}$ of MTT $(5 \mathrm{mg} / \mathrm{ml})$ was added to incubate for $4 \mathrm{~h}$ at $37^{\circ} \mathrm{C}$. The supernatant was discarded and the formazan crystal was dissolved with DMSO (100 $\mu \mathrm{l} /$ well). The absorbance was measured at $570 \mathrm{~nm}$ using a microplate reader (Thermo Scientific) [39].

\section{Enzyme-linked immunosorbent assay (ELISA)}

Levels of IL- 6 and TNF- $\alpha$ in cell supernatants and BALF were quantified with ELISA kits according to the manufacturers' instructions. 


\section{Confocal Microscopy}

RAW264.7 cells were seeded in a glass bottom dish and exposed to LGS for $24 \mathrm{~h}$ followed by stimulation with LPS for $2 \mathrm{~h}$. Cells were rinsed with phosphate-buffered saline (PBS, PH 7.2) for three times, fixed with $4 \%$ paraformaldehyde for $15 \mathrm{~min}$, permeabilized with 0.2 $\%$ Triton X-100 for $15 \mathrm{~min}$ at room temperature (RT). After blocking with $5 \%$ bovine serum albumin in PBS for $1 \mathrm{~h}$, cells were incubated with NF- $\mathrm{kB}$ p65 antibody at $4{ }^{\circ} \mathrm{C}$ overnight. Alexa Fluor 488 secondary antibody was used in dark for $1 \mathrm{~h}$ at $37^{\circ} \mathrm{C}$ before stained with $4^{\prime}$, 6-diamidino-2-phenylindole (DAPI) for $5 \mathrm{~min}$ to visualize the nuclei. Fluorescent images were photographed using a confocal microscope (Nikon) [40].

\section{Transient transfection with siRNA}

RAW264.7 cells were seeded in a 6-well plate at $40 \%$ confluence overnight. The $\alpha 7 \mathrm{nAchR}$ siRNA (120 $\mathrm{nM}$ ) was transfected into cells with Lipofectamine 3000 transfection reagent for $24 \mathrm{~h}$ in OPTI-MEM (Gibco) according to the manufacturer's instruction and western blotting was further conducted to confirm the silence effects.

\section{Preparation of total and nuclear proteins}

For total protein extraction, the harvested cells or lung tissue $(\sim 20 \mathrm{mg})$ were lysed in lysis buffer $(50 \mathrm{mM}$ Tris, $\mathrm{pH} 7.5,1 \%$ Triton X-100, $150 \mathrm{mM} \mathrm{NaCl}, 1 \mathrm{mM}$ EDTA, $1 \mathrm{mM}$ PMSF, $1 \mathrm{mM} \mathrm{Na}_{3} \mathrm{VO}_{4}, 1 \mathrm{mM}$ dithiothreitol, 1 $\mathrm{mM}$ phosphatase inhibitor) for $30 \mathrm{~min}$ on ice and vortexed $15 \mathrm{~s}$ with $10 \mathrm{~min}$ interval. Samples were centrifugated at $12000 \mathrm{rpm}$ at $4{ }^{\circ} \mathrm{C}$ for $15 \mathrm{~min}$ and the supernatants were harvested and stored at $-80^{\circ} \mathrm{C}$. Nuclear extract was prepared according to the manufacturers' instructions of nuclear and cytoplasmic protein extraction kit. Protein concentrations were determined with a BCA protein assay kit [39].

\section{Western blotting}

Protein expression levels were determined by western blotting analysis. Equal amount of protein samples were separated on a $10 \%$ SDS-polyacrylamide gel electrophoresis and transferred onto a PVDF membrane (Bio-Rad). After blocking with 5\% skim milk in Trisbuffered saline containing $0.1 \%$ Tween-20 (TBS-T) for $1 \mathrm{~h}$, membrane was incubated with primary antibody overnight at $4{ }^{\circ} \mathrm{C}$, and probed with appropriate secondary antibody conjugated with horseradish peroxidase (Cell signaling Technology) for $1 \mathrm{~h}$ at RT. Bolts were detected using enhanced chamiluminescence (ECL) reagents (Bio-
Rad, Hercules, CA) [39].

\section{Electrophoretic mobility shift assay (EMSA)}

Nuclear extracts were prepared as previously described. The biotin-labeled and unlabeled doublestranded oligonucleotides containing a consensus NF- $\mathrm{KB}$ sequence 5'-AGT TGA GGG GAC TTT CCC AGG$3^{\prime}$ ' and its complementary strand (Beyotime) were used as the probe. EMSA was performed according to the manufacturer's protocol.

\section{Acetyl cholinesterase activity assay}

Levels of acetyl cholinesterase activity in BALF were quantified with acetyl cholinesterase kit according to the manufacturers' protocol.

\section{Histopathological and immunohistochemical observation of Lung}

One lobe of right lung tissues was fixed with $4 \%$ $(w / v)$ paraformaldehyde for $24 \mathrm{~h}$. Samples were dehydrated in graded ethanol and embedded in paraffin. Some sections with $5-\mu \mathrm{m}$ thick were stained with hematoxilin and eosin (H \& E) and observed by light microscopy (Olympus IX 53). The other lung slides were incubated in citrate antigen retrieval solution (Boster) for 10 minutes at $95{ }^{\circ} \mathrm{C}$ and cooled to RT. Sections were washed and incubated in 0.3 $\% \mathrm{H}_{2} \mathrm{O}_{2}$ to quench endogenous peroxidase activity for 10 min before blocking for $2 \mathrm{~h}$ with $10 \%$ BSA in PBS at RT. Then, slides were incubated with NF-kB p65 antibody (1 : 800 ) overnight at $4{ }^{\circ} \mathrm{C}$ and secondary antibody conjugated with horseradish peroxidase $(1: 1000)$ for $45 \mathrm{~min}$ at 37 ${ }^{\circ} \mathrm{C}$. Specific labeling was performed with DAB substrate kit and specimens were counterstained with hematoxilin before being observed by light microscopy (Olympus IX $53)$.

\section{Transmission electron microscope ultrastructural observation}

After LGS treatment, lung specimens were immediately fixed in PBS containing 2.5\% glutaraldehyde and stored at $4{ }^{\circ} \mathrm{C}$ overnight. Tissue samples were postfixed in osmium tetroxide and embedded in Spurr's resin. Ultrathin sections $(50 \mathrm{~nm})$ were collected and stained with $1 \%$ uranyl acetate and $0.2 \%$ lead citrate before observed by transmission electron microscopy (Hitachi H-7650). 


\section{Lung wet/dry weight (W/D) ratio measurement}

Lung tissues were weighed to obtain the wet weight (W) and then placed in an oven at $60{ }^{\circ} \mathrm{C}$ for $72 \mathrm{~h}$ to obtain the dry weight (D). To assess the tissue edema, W/D ratio was calculated by the following formula: wet weight/dry weight $\times 100 \%$.

\section{Protein levels, cell count and MPO activity in BALF}

After LPS treatment for $8 \mathrm{~h}$, the rats were anesthetized with $10 \%(\mathrm{w} / \mathrm{v})$ pentobarbital sodium solution and were inserted with a plastic cannula into the trachea. BALF was performed with three aliquots of $1 \mathrm{ml}$ PBS instilled up to a total volume of $3 \mathrm{ml}$. BALF samples were centrifuged $\left(3000 \mathrm{rpm}, 4{ }^{\circ} \mathrm{C}\right)$ for $10 \mathrm{~min}$ and supernatants were stored at $-80{ }^{\circ} \mathrm{C}$ for subsequent analysis. The protein concentrations in BALF supernatants were measured by a BCA protein assay kit. The sediment cells were re-suspended in $50 \mu 1$ PBS and total BALF cells were counted double-blindly using a hemacytometer, following leukocytes differential counting which were stained with Wright Giemsa. MPO activity in the BALF was measured with MPO determination kit according to the manufacturers' instruction. Absorbance was measured at $460 \mathrm{~nm}$ on a microplate reader (Thermo Scientific).

\section{Statistical analysis}

Results are presented as the mean \pm standard deviation (S.D.) from 3 independent experiments at least. The data was analyzed by Graph Pad Prism 5.0 (Graph Pad, La Jolla, CA). $P<0.05$ was considered statistically significant.

\section{GRANT SUPPORT}

This work was supported by the National Science Foundation of China (81072747, 81373539, 81402801 and 81573671 ) and Natural Science Foundation of Guangdong Province (2014A030313306 and 2014A030310250).

\section{CONFLICTS OF INTEREST}

No potential conflicts of interest were identified by any of the authors.

\section{REFERENCES}

1. Tracey KJ, Beutler B, Lowry SF, Merryweather J, Wolpe S, Milsark IW, Hariri RJ, Fahey TR, Zentella A, Albert JD and Et A. Shock and tissue injury induced by recombinant human cachectin. Science. 1986; 234:470-474.
2. Tracey KJ, Fong Y, Hesse DG, Manogue KR, Lee AT, Kuo GC, Lowry SF and Cerami A. Anti-cachectin/TNF monoclonal antibodies prevent septic shock during lethal bacteraemia. Nature. 1987; 330:662-664.

3. Rubenfeld GD and Herridge MS. Epidemiology and outcomes of acute lung injury. Chest. 2007; 131:554-562.

4. Borovikova LV, Ivanova S, Zhang M, Yang H, Botchkina GI, Watkins LR, Wang H, Abumrad N, Eaton JW and Tracey KJ. Vagus nerve stimulation attenuates the systemic inflammatory response to endotoxin. Nature. 2000; 405:458-462.

5. Wang H, Yu M, Ochani M, Amella CA, Tanovic M, Susarla S, Li JH, Wang H, Yang H, Ulloa L, Al-Abed Y, Czura CJ and Tracey KJ. Nicotinic acetylcholine receptor alpha7 subunit is an essential regulator of inflammation. Nature. 2003; 421:384-388

6. Wang H, Liao H, Ochani M, Justiniani M, Lin X, Yang L, Al-Abed Y, Wang H, Metz C, Miller EJ, Tracey KJ and Ulloa L. Cholinergic agonists inhibit HMGB1 release and improve survival in experimental sepsis. Nat Med. 2004; 10:1216-1221.

7. Saeed RW, Varma S, Peng-Nemeroff T, Sherry B, Balakhaneh D, Huston J, Tracey KJ, Al-Abed Y and Metz CN. Cholinergic stimulation blocks endothelial cell activation and leukocyte recruitment during inflammation. J Exp Med. 2005; 201:1113-1123.

8. Yang YH, Li DL, Bi XY, Sun L, Yu XJ, Fang HL, Miao Y, Zhao M, He X, Liu JJ and Zang WJ. Acetylcholine Inhibits LPS-Induced MMP-9 Production and Cell Migration via the alpha7 nAChR-JAK2/STAT3 Pathway in RAW264.7 Cells. Cell Physiol Biochem. 2015; 36:2025-2038.

9. de Jonge WJ and Ulloa L. The alpha7 nicotinic acetylcholine receptor as a pharmacological target for inflammation. Br J Pharmacol. 2007; 151:915-929.

10. Tracey KJ. The inflammatory reflex. Nature. 2002; 420:853859.

11. Pavlov VA, Ochani M, Yang LH, Gallowitsch-Puerta M, Ochani K, Lin X, Levi J, Parrish WR, Rosas-Ballina M, Czura CJ, Larosa GJ, Miller EJ, Tracey KJ and Al-Abed Y. Selective alpha7-nicotinic acetylcholine receptor agonist GTS-21 improves survival in murine endotoxemia and severe sepsis. Crit Care Med. 2007; 35:1139-1144.

12. Mabley J, Gordon S and Pacher P. Nicotine exerts an antiinflammatory effect in a murine model of acute lung injury. Inflammation 2011; 34:231-237.

13. Su X, Lee JW, Matthay ZA, Mednick G, Uchida T, Fang X, Gupta N and Matthay MA. Activation of the alpha7 nAChR reduces acid-induced acute lung injury in mice and rats. Am J Respir Cell Mol Biol. 2007; 37:186-192.

14. Deng ZJ. (2010). Chinese Press of Chinese Traditional Medicine. Science of Prescriptions. 102-103.

15. Zhang WX and Ding P. The experience of Doctor Wang Jinda on treating Acute Respiratory Distress Syndyome with Lianggesan. J Tradit Chin Med. 2013; 54:615-616. 
16. Hu KY, Yu LZ, Chen YY and Lin XC. A study on the protective effect of Lianggesan in rat acute lung injury. Pharmacol Clin Chin Mate Med. 2008; 24:3-5

17. Hu KY and Yu LZ. Effect of Lianggesan on T Helper Cell Shift in Rats with Acute Lung Injury by Endotoxin. J Tradit Chin Med. 2009; 50:1023-1025.

18. Cheng BC, Ma XQ, Kwan HY, Tse KW, Cao HH, Su T, Shu X, Wu ZZ and Yu ZL. A herbal formula consisting of Rosae Multiflorae Fructus and Lonicerae Japonicae Flos inhibits inflammatory mediators in LPS-stimulated RAW 264.7 macrophages. J Ethnopharmacol. 2014; 153:922-927.

19. Hamada S, Takada H, Ogawa T, Fujiwara T and Mihara J. Lipopolysaccharides of oral anaerobes associated with chronic inflammation: chemical and immunomodulating properties. Int Rev Immunol. 1990; 6:247-261.

20. Zhang G and Ghosh S. Toll-like receptor-mediated NFkappaB activation: a phylogenetically conserved paradigm in innate immunity. J Clin Invest. 2001; 107:13-19.

21. Bonizzi G and Karin M. The two NF-kappaB activation pathways and their role in innate and adaptive immunity. Trends Immunol. 2004; 25:280-288.

22. Sun Y, Li Q, Gui H, Xu DP, Yang YL, Su DF and Liu $\mathrm{X}$. MicroRNA-124 mediates the cholinergic antiinflammatory action through inhibiting the production of pro-inflammatory cytokines. Cell Res. 2013; 23:1270-1283.

23. Ochs M. A brief update on lung stereology. J Microsc Oxford. 2006; 222:188-200.

24. Schneider JP, Pedersen L, Muhlfeld C and Ochs M. Staining histological lung sections with Sudan Black B or Sudan III for automated identification of alveolar epithelial type II cells. Acta Histochem. 2015; 117:675-680.

25. Rubenfeld GD, Caldwell E, Peabody E, Weaver J, Martin DP, Neff M, Stern EJ and Hudson LD. Incidence and outcomes of acute lung injury. N Engl J Med. 2005; 353:1685-1693.

26. Abraham E, Carmody A, Shenkar R and Arcaroli J. Neutrophils as early immunologic effectors in hemorrhageor endotoxemia-induced acute lung injury. Am J Physiol Lung Cell Mol Physiol. 2000; 279:L1137-L1145.

27. Ware LB and Matthay MA. The acute respiratory distress syndrome. N Engl J Med. 2000; 342(18):1334-1349.

28. Takala A, Jousela I, Takkunen O, Kautiainen H, Jansson SE, Orpana A, Karonen SL and Repo H. A prospective study of inflammation markers in patients at risk of indirect acute lung injury. Shock. 2002; 17:252-257.

29. Ghosh S and Hayden MS. New regulators of NF-kappaB in inflammation. Nat Rev Immunol. 2008; 8:837-848.

30. Skok MV. Neuronal nicotinic receptors: structure and function in different types of cells. Ukr Biokhim Zh (1999). 2004; 76:5-15.
31. Leonard S and Bertrand D. Neuronal nicotinic receptors: from structure to function. Nicotine Tob Res. 2001; 3:203223.

32. Le Novere $\mathrm{N}$ and Changeux JP. Molecular evolution of the nicotinic acetylcholine receptor: an example of multigene family in excitable cells. J Mol Evol. 1995; 40:155-172.

33. van Maanen MA, Stoof SP, van der Zanden EP, de Jonge WJ, Janssen RA, Fischer DF, Vandeghinste N, Brys R, Vervoordeldonk MJ and Tak PP. The alpha7 nicotinic acetylcholine receptor on fibroblast-like synoviocytes and in synovial tissue from rheumatoid arthritis patients: a possible role for a key neurotransmitter in synovial inflammation. Arthritis Rheum. 2009; 60:1272-1281.

34. Waldburger JM, Boyle DL, Pavlov VA, Tracey KJ and Firestein GS. Acetylcholine regulation of synoviocyte cytokine expression by the alpha7 nicotinic receptor. Arthritis Rheum. 2008; 58:3439-3449.

35. Sun P, Zhou K, Wang S, Li P, Chen S, Lin G, Zhao Y and Wang $T$. Involvement of MAPK/NF-kappaB signaling in the activation of the cholinergic anti-inflammatory pathway in experimental colitis by chronic vagus nerve stimulation. PLoS One. 2013; 8:e69424.

36. Yoshikawa H, Kurokawa M, Ozaki N, Nara K, Atou K, Takada E, Kamochi H and Suzuki N. Nicotine inhibits the production of proinflammatory mediators in human monocytes by suppression of I-kappaB phosphorylation and nuclear factor-kappaB transcriptional activity through nicotinic acetylcholine receptor alpha7. Clin Exp Immunol. 2006; 146:116-123.

37. Li Q, Zhou XD, Kolosov VP and Perelman JM. Nicotine reduces TNF-alpha expression through a alpha7 $\mathrm{nAChR} /$ MyD88/NF-kB pathway in HBE16 airway epithelial cells. Cell Physiol Biochem. 2011; 27:605-612.

38. Hu JL, Shao M and Yu LZ. HPLC-DAD fingerprint of Lianggesan Decoction. Chin Tradit HER Drugs. 2014; 45:50-54.

39. Zhang DM, Liu JS, Tang MK, Yiu A, Cao HH, Jiang L, Chan JY, Tian HY, Fung KP and Ye WC. Bufotalin from Venenum Bufonis inhibits growth of multidrug resistant HepG2 cells through G2/M cell cycle arrest and apoptosis. Eur J Pharmacol. 2012; 692:19-28.

40. Zhang DM, Liu JS, Deng LJ, Chen MF, Yiu A, Cao HH, Tian HY, Fung KP, Kurihara H, Pan JX and Ye WC. Arenobufagin, a natural bufadienolide from toad venom, induces apoptosis and autophagy in human hepatocellular carcinoma cells through inhibition of $\mathrm{PI} 3 \mathrm{~K} / \mathrm{Akt} / \mathrm{mTOR}$ pathway. Carcinogensis. 2013; 34:1331-1342. 